\title{
Familial glucocorticoid deficiency
}

\section{Studies of diagnosis and pathogenesis}

\author{
D. Thistlethwaite, J. A. B. DARLING, R. FRASER, P. A. MASON, L. H. REES, and \\ R. A. HARKNESS
}

From the Department of Paediatric Biochemistry, Royal Hospital for Sick Children, Edinburgh; Department of Child Life and Health, University of Edinburgh; MRC Blood Pressure Unit, Western Infirmary, Glasgow; and Department of Chemical Pathology, St. Bartholomew's Hospital, London

\begin{abstract}
Thistlethwaite, D., Darling, J. A. B., Fraser, R., Mason, P. A., Rees, L. H., and Harkness, R. A. (1975). Archives of Disease in Childhood, 50, 291. Familial glucocorticoid deficiency: studies of diagnosis and pathogenesis. The clinical and biochemical findings are described in 2 brothers who had intermittent hypoglycaemia generally precipitated by the 'stress' of infection. Both were tall and pigmented. Both boys showed a failure of adrenocortical response to ACTH which was progressive in the eldest boy. The diagnosis of familial glucocorticoid deficiency (hereditary adrenocortical unresponsiveness) was confirmed by the absence of electrolyte imbalance even on a low sodium diet, and by very high levels of ACTH in plasma. High levels of deoxycorticosterone (DOC) were found in both children with normal levels of other plasma corticosteroids.

It is suggested that the high levels of DOC may be in some way related to the apparent persistence of a 'fetal' type of adrenocortical steroid biosynthesis for 18 months or more in these boys. After the diagnosis, established by relatively simple methods, treatment with cortisone acetate has been highly effective.
\end{abstract}

In 1959 Shepard, Landing, and Mason described 2 sisters with pigmentation of the skin, marked muscular weakness, and convulsions. The second sister had low levels of plasma 11-hydroxycorticosteroid which failed to respond to ACTH. Aldosterone secretion was judged to be unaffected by virtue of normal serum electrolyte concentration and blood pressure on a salt restricted diet. Since that time a further 10 families with similarly affected children have been described (Stempfel and Engel, 1960; Williams and Freeman, 1965; Migeon, et al., 1968; Franks and Nance, 1970; Kelch et al., 1972; Kershnar, Roe, and Kogut, 1972; Moshang et al., 1973). The condition has been given various names. Both familial glucocorticoid deficiency and hereditary adrenocortical unresponsiveness to ACTH have been recently adopted. The history is typical of recurrent hypoglycaemia, starting in the second year of life, with associated vomiting, convulsions, or coma. Neurological sequelae and otherwise unexplained deaths among relatives have

Received 7 October 1974. been recorded. Pigmentation may be present from the early days of life and is especially marked on the dorsal surface of the hands. Affected children are generally tall.

This paper describes the clinical and laboratory findings in 2 brothers with familial glucocorticoid deficiency. The complex biochemical changes found have been discussed in view of their possible importance in the pathogenesis of the condition:

\section{Case reports}

Case A. The first child of young healthy, unrelated parents with no family history of endocrine disease or unexplained childhood deaths. The pregnancy, dedelivery, and subsequent progress in the first year of life were normal. Birthweight was $3.9 \mathrm{~kg}$. He first showed symptoms of the condition at the age of 21 months and was diagnosed at the age of 4 years 7 months.

At the first admission, which was similar to five later admissions, he was noted to have been irritable and listless for a period of 2 days. During the second day he began vomiting, and 2 hours before admission he had become increasingly unresponsive; he was first limp and then stiff. On admission he was sweating, coma- 
tose, and responsive only to painful stimuli. Blood pressure was normal $(90 / 60 \mathrm{mmHg})$. Neurological examination revealed no focal signs, but he was hypertonic with clonic movements in all limbs. Pigmentation was especially marked on the dorsal sufaces of the interphalangeal joints and present on face, neck, and the areas of the legs exposed to daylight. His weight and height $(14.15 \mathrm{~kg}$ and $86.5 \mathrm{~cm})$ were 2SD above the mean for Edinburgh children. Serum concentrations of sodium and potassium were repeatedly normal, ranging from 133 to $140 \mathrm{mEq} / 1$ and from 3 to $6.2 \mathrm{mEq} / \mathrm{l}$, respectively. There was acidosis, plasma $p \mathrm{H}$ ranging from $7 \cdot 02$ to $7 \cdot 3$, and ketosis with accompanying mild dehydration. The most striking abnormality on each admission was a plasma glucose concentration of $<40$ $\mathrm{mg} / 100 \mathrm{ml}$.

On two admissions there was definite evidence of infection, viral meningitis, and chickenpox. On two other occasions, a high mycoplasma titre (1 in 640) and Haemophilus influenzae grown from a throat swab indicated likely pathogens. These infections appeared to precipitate hypoglycaemia.

Treatment over a 24-hour period included initial rapid correction of the hypoglycaemia with $25 \%$ dextrose followed by correction of fluid and acid-base balance with $0.45 \%$ saline in $5 \%$ dextrose and aliquots of $8.4 \%$ sodium bicarbonate (w/v). After treatment on the first admission the haemoglobin concentration fell from $14 \cdot 1 \mathrm{~g} / \mathrm{dl}$ to $11 \mathrm{~g} / \mathrm{d}$. On the last occasion, with glucocorticoid failure then proven, intravenous hydrocortisone resulted in a rapid return to normality within 8 hours.

Clinical progress. Between attacks the child remained well and developed normally, but was described by his parents as bad tempered and difficult. He continued to grow at a rate above the 97th centile and showed advanced bone maturity with a bone age of 5.7 years for a chronological age of 4.4 years (Tanner, Whitehouse, and Healy, 1962). He is of normal intelligence with an IQ of 104 on the Stanford-Binet scale, but he does show evidence of minimal cerebral dysfunction with mild truncal ataxia. From the time of the first admission pigmentation spread to involve the nipples, trunk, and scrotum. However, since the start of treatment with cortisone acetate, $5 \mathrm{mg}$ twice daily, the pigmentation has diminished.

Case B. At the time of diagnosis he was 1 year 7 months. He was the second child, born at term weighing $3.1 \mathrm{~kg}$ after a normal pregnancy and delivery. Pigmentation of the hands was noted at 4 weeks of age. He required admission to hospital at 4 months with bronchiolitis, from which recovery was uneventful. Progress was normal until 18 months of age, when he developed a febrile illness at the same time as his brother was admitted with chickenpox. Over a 24-hour period he became increasingly listless and in the 6 hours before admission began vomiting. On admission he was drowsy but could be roused by voice. He was sweating, mildly dehydrated and ketotic; plasma $P H$ was $7 \cdot 15$ and standard bicarbonate $10 \mathrm{mEq} / 1$. He had mild pharyngitis and was thought to be in the prodromal phase of chickenpox. Pigmentation was present in a distribution similar to that recorled for his brother. His height and weight were more than 2SD above the mean; his bone age was equivalent to his chronological age. Plasma glucose was $25 \mathrm{mg} / 100 \mathrm{ml}$ and serum electrolytes were normal, serum sodium and potassium concentrations being 135 and $4.6 \mathrm{mEq} / 1$, respectively. He responded rapidly to treatment which included intravenous hydrocortisone. This boy has remained well on cortisone acetate, $7.5 \mathrm{mg} /$ day.

\section{Methods}

In order to minimize degradation of hormones, blood was collected in lithium heparin tubes, separated immediately, stored, and transported deep frozen in plastic tubes. Urine was collected without added preservatives and stored at $4^{\circ} \mathrm{C}$.

\section{Hormone assays.}

Plasma ACTH, MSH. ACTH was extracted from plasma samples with porous glass beads (Ratcliffe and Edwards, 1971) and values corrected for losses occurring during this procedure.

(a) Radioimmunoassay. In principle the assay procedure was as previously described (Rees et al., 1971) with minor modifications; natural human ACTH (Lerner-Upton fraction 88) was used for iodination and standardization and a different antiserum was employed. This was raised by immunization of a rabbit with tetracosactrin (Synacthen, $\alpha^{1-24}$ ACTH, Ciba) conjugated by the carbodimide reaction to rabbit serum albumin and emulsified in Freund's adjuvant (Difco Laboratories, Detroit, Michigan). This antibody reacts equally with all ACTH analogues $\left(\alpha-\mathrm{MSH}, \alpha^{1-24} \mathrm{ACTH}\right)$ that share the N-terminal 13 amino acid sequence of ACTH. $\beta_{\mathrm{h}} \mathrm{MSH}$, which contains amino acid sequence 4-10 $\mathrm{ACTH}$, and $\alpha^{1-10}$ ACTH were far less reactive with this antibody.

(b) Bioassay. The method of Lipscomb and Nelson (1962) modified by Ney et al. (1963) was used. In this technique, fluorogenic corticosterone secretion (Mattingly, 1962) into the left adrenal vein of 2-hour posthypophysectomy male Sprague-Dawley rats $(200-250 \mathrm{~g})$ was measured as an index of the ACTH concentration in the injected material Native porcine ACTH (Third International Standard, Bangham, Mussett, and StackDunne, 1962) was employed as standard. Bioassay values were converted to weight for comparison with radioimmunoassay values assuming a biological potency for the Lerner-Upton ACTH of $101 \pm 19$ (SD) IU/mg (Besser et al., 1971b).

(c) Radioimmunoassay for $\beta-M S H$. $\beta$-MSH was measured in unextracted plasma (J. Gilkes, personal communication, 1974) using an antiserum raised by immunization of a rabbit with impure procine ACTH. The antiserum did not show any cross-reactivity with ACTH or $\beta$-MSH. Synthetic human $\beta-$ MSH (Ciba) Geigy) was used for iodination and as standard. 
(d) Specific corticosteroid assays. Concentrations of 6 corticosteroid hormones, aldosterone, corticosterone, 11-deoxycorticosterone (DOC), 18-hydroxydeoxycorticosterone (18-OH-DOC), cortisol, and 11-deoxycortisol, in plasma were measured by gas-liquid chromatography (Mason and Fraser, 1975), using the electron-capturing ability of steroid heptafluorobutyrate derivatives (Exley and Chamberlain, 1967). The problem of recurrent detector contamination was overcome by the use of a bypass valve (Wilson and Fraser, 1971; Wilson, 1973). Quality control data for the period in which the assays were carried out were obtained by including samples of a normal human plasma pool in each series of assays.

Plasma growth hormone and thyroid stimulating hormone were measured by the methods of Hunter and Greenwood (1964) and Irvine et al., (1973), respectively. Plasma 'cortisol' or 11-OHCS was estimated by spectrofluorometry using a method similar to that of Mattingly (1962).

Urine. Urinary 17-hydroxycorticosteroids (17OHCS) were measured by the method of Few (1960). Group analysis of urinary steroids was performed by a simplified form of the method of Darling and Harkness (1973), consisting of gas chromatography after $\mathrm{CrO}_{3}$ oxidation of an acid hydrolysed urine extract. The reliability criteria of the method are satisfactory. Specificity was examined by gas chromatography-mass spectrometry, as in the studies on milk (see Darling et al., 1972). The results of such group analyses have been given under the title ' $17-$ and 20-oxogenic steroids' since the steroids produced have 17- or 20oxo groups. Pregnanetriol was determined by the method of Harkness and Love (1966). Gonadotrophins (FSH and LH) in urine and blood were determined by radioimmunoassay (Fraser et al., 1973).

Other investigations. Plasma glucose was determined by a specific glucose oxidase based method. Other biochemical investigations were performed by standard methods generally using micromanual procedures. Urinary ketones were examined by direct gas-liquid chromatography of urine on a PEG-400 coated column at $40^{\circ} \mathrm{C}$. Only normal ketones were found. No abnormal accumulation of more volatile organic acids was found using the modified method of Tanaka et al., (1966). There was thus no evidence of a metabolic block in some of the central areas of intermediary metabolism.

\section{Clinical investigation}

Pigmentation was noted and adrenal hypofunction suspected at the elder boy's second admission. The urinary excretions of $17-\mathrm{OHCS}$ were $2,2 \cdot 1$, and $3 \mathrm{mg} /$ $24 \mathrm{~h}$. These values were normal and further investigation of adrenal function was not carried out. Investigation to find a cause of hypoglycaemia included an extended glucose tolerance test, glucagon tests when both hypoglycaemic and normoglycaemic, the tolbutamide test, and insulin assay during hypoglycaemic periods. These results were normal apart from the glucagon test carried out with the child hypoglycaemic and ketotic, when results were consistent with depletion of liver glycogen. A ketogenic diet on these occasions promoted ketosis at 12 hours, but no hypoglycaemia over a 24-hour period. Other investigations were negative, including a full blood count, serum concentrations of electrolytes, calcium, phosphate, alkaline phosphatase, iron, iron binding capacity, and copper oxidase. More conventional liver function tests were normal. Paper chromatography of serum and urinary amino acids revealed no abnormality. Urinary porphyrins, urobilinogen, and reducing sugars were normal. Radiological examination of skull showed a normal pituitary fossa, and of abdomen, no adrenal calcification. The Heaf tests were negative, No autoantibodies were found to adrenal, thyroid, or other endocrine tissues.

Endocrine investigation. While hypoglycaemia associated with pigmentation suggested adrencortical hypofunction, normal 'basal' urinary excretion of 17OHCS and the absence of disturbances of serum sodium and potassium concentrations during the acute episodes did not appear to be consistent with adrenocortical failure. Recent reports of similar cases (Kelch $e t$ al., 1972; Kershnar et al., 1972; Moshang et al., 1973) stimulated further investigation of adrenal function.

Prolonged stimulation with ACTH gel intramuscularly in a dose of $2 \mathrm{mg} / \mathrm{kg}$ per $24 \mathrm{~h}$ for 48 hours produced no rise in urinary excretion of 17-OHCS or pregnanetriol in either boy, except possibly in $A$ on the 'postACTH' day (Table I). Basal excretion in $A$ had now

TABLE I

Urinary steroid response to corticotrophin gel in 2 boys $\mathrm{A}$ and B (2mg/kg per $24 \mathrm{~h}$ for $48 \mathrm{~h})$

\begin{tabular}{|c|c|c|c|c|c|c|}
\hline \multirow{3}{*}{ Day } & \multicolumn{6}{|c|}{ Urinary excretion of } \\
\hline & \multicolumn{2}{|c|}{$\begin{array}{l}17-O H C S \\
(\mathrm{mg} / 24 \mathrm{~h})\end{array}$} & \multicolumn{2}{|c|}{$\begin{array}{c}\text { Pregnane- } \\
\text { triol } \\
(\mu \mathrm{g} / 24 \mathrm{~h})\end{array}$} & \multicolumn{2}{|c|}{$\begin{array}{l}\text { Creatinine } \\
(\mathrm{mg} / 24 \mathrm{~h})\end{array}$} \\
\hline & $A$ & $\boldsymbol{B}$ & $A$ & $\boldsymbol{B}$ & $A$ & $\boldsymbol{B}$ \\
\hline $\begin{array}{l}\text { Basal } 1 \\
\text { Basal } 2 \\
\text { ACTH } 1 \\
\text { ACTH } 2 \\
\text { Post-ACTH }\end{array}$ & $\begin{array}{l}0 \cdot 41 \\
0 \cdot 16 \\
0 \cdot 34 \\
0 \cdot 62 \\
1 \cdot 4\end{array}$ & $\begin{array}{l}2 \cdot 15 \\
3 \cdot 0 \\
2 \cdot 25 \\
1 \cdot 3 \\
1 \cdot 7\end{array}$ & $\begin{array}{l}- \\
- \\
0 \cdot 8 \\
2 \cdot 2 \\
6 \cdot 5\end{array}$ & $\begin{array}{l}35 \cdot 2 \\
76 \cdot 7 \\
37 \cdot 6 \\
9 \cdot 5 \\
6 \cdot 0\end{array}$ & $\begin{array}{l}335 \\
384 \\
420 \\
278 \\
225\end{array}$ & $\begin{array}{l}210 \\
193 \\
191 \\
154 \\
148\end{array}$ \\
\hline
\end{tabular}

fallen to abnormally low levels despite normal output at an earlier age. The younger brother $(B)$ still had normal basal output. These results were supported by the urinary excretion of ' 17 - and 20-oxogenic steroids' (Table II). Though some variation in creatinine excretion was found (Table I), this was not sufficient to account for these results. Thus, there was clear evidence of a failure of response to ACTH (Clayton, Edwards, and Renwick, 1963). This was later confirmed by the extremely high levels of ACTH found by radioimmunoassay and on bioassay (Table III A and B). There was reasonably good agreement between the bioassay and radioimmunoassay in the one com- 
TABLE II

Urinary '17- and 20-oxogenic' steroid response of 2 boys A and B to corticotrophin gel ( $2 \mathrm{mg} / \mathrm{kg}$ per $24 \mathrm{~h}$ for $48 \mathrm{~h}$ )

\begin{tabular}{|c|c|c|c|c|c|c|c|c|}
\hline \multirow{3}{*}{ Day } & \multicolumn{8}{|c|}{$\mu_{\mathrm{g}}$ in $24 \mathrm{~h}$} \\
\hline & \multicolumn{2}{|c|}{$\begin{array}{l}5 \beta \text {-androstane- } \\
\text { 3. 17-dione }\end{array}$} & \multicolumn{2}{|c|}{$\begin{array}{c}5 \alpha \text {-androstane- } \\
3,17 \text {-dione }\end{array}$} & \multicolumn{2}{|c|}{$\begin{array}{c}\text { 5 } \beta \text {-pregnane- } \\
3,20 \text {-dione }\end{array}$} & \multicolumn{2}{|c|}{$\begin{array}{c}5 \alpha \text {-pregnane- } \\
3,20 \text {-dione }\end{array}$} \\
\hline & $A$ & $\boldsymbol{B}$ & $A$ & $\boldsymbol{B}$ & $A$ & $\boldsymbol{B}$ & $A$ & $\boldsymbol{B}$ \\
\hline $\begin{array}{l}\text { Basal } 1 \\
\text { Basal } 2 \\
\text { ACTH } 1 \\
\text { ACTH } 2 \\
\text { Post-ACTH }\end{array}$ & $\begin{array}{r}4 \cdot 1 \\
4 \cdot 4 \\
13 \cdot 0 \\
22 \cdot 0 \\
46 \cdot 0\end{array}$ & $\begin{array}{l}34 \cdot 0 \\
45 \cdot 8 \\
40 \cdot 5 \\
26 \cdot 7 \\
27 \cdot 4\end{array}$ & $\begin{array}{r}4 \cdot 6 \\
6 \cdot 8 \\
6 \cdot 9 \\
6 \cdot 8 \\
10 \cdot 6\end{array}$ & $\begin{array}{r}5 \cdot 5 \\
5 \cdot 7 \\
7 \cdot 3 \\
5 \cdot 2 \\
16 \cdot 6\end{array}$ & $\begin{array}{l}1 \cdot 3 \\
1 \cdot 5 \\
12 \cdot 2 \\
3 \cdot 1 \\
10 \cdot 0\end{array}$ & $\begin{array}{r}- \\
10 \cdot 9 \\
9 \cdot 2 \\
4 \cdot 3 \\
5 \cdot 7\end{array}$ & $\begin{array}{l}0 \cdot 8 \\
0 \cdot 3 \\
0.9 \\
2 \cdot 1 \\
6 \cdot 5\end{array}$ & $\begin{array}{l}-\overline{1 \cdot 7} \\
2 \cdot 5 \\
0 \cdot 8 \\
8 \cdot 0\end{array}$ \\
\hline
\end{tabular}

parison made. Plasma 11-OHCS or 'cortisol' concentrations were difficult to interpret and might have been misleading (Table IV). $B$ responded to tetracosactrin by approximately doubling the concentration of 11OHCS; $A$ did not respond, but his zero time concentration was higher than all his previous results which, though somewhat low, were probably not abnormal. The corticosteroid response to hypoglycaemia was deficient in both boys, especially in $A$. There was, however, clear evidence of a diurnal variation in plasma 11-OHCS and ACTH.

Estimates of plasma cortisol by a more specific method (Table V) showed concentrations at the lower end of the normal range with high levels of DOC. This may account for some of the misleading results in 11OHCS (Table IV), despite the precautions taken to

\section{TABLE IIIA}

Circadian variations in plasma immunoreactive $A C T H$ concentrations in 2 boys $\mathrm{A}$ and $\mathrm{B}$

\begin{tabular}{ll|c|c}
\hline & \multirow{2}{*}{$\begin{array}{c}\text { Time } \\
\text { (h) }\end{array}$} & N-Terminal ACTH $(\mathrm{pg} / \mathrm{ml})$ \\
\cline { 2 - 3 } & & $A$ & $B$ \\
\hline 09.00 & & 6888 & 4050 \\
23.00 & & 4626 & 1938 \\
09.00 & & $5150^{\star}$ & \\
\hline
\end{tabular}

\#Bioactive ACTH (pg/ml) 3280. Normal range of immunoreactive N-terminal ACTH $<10-80 \mathrm{pg} / \mathrm{ml}$.

TABLE IIIB

Response of plasma immunoreactive ACTH and $\beta$ $M S H$ concentrations to treatment of A

\begin{tabular}{l|c|c}
\hline & \multicolumn{2}{|c|}{$\mathbf{p g} / \mathrm{ml}$} \\
\cline { 2 - 3 } & $\begin{array}{c}\text { Before } \\
\text { treatment }\end{array}$ & $\begin{array}{c}\text { After } \\
\text { treatment }\end{array}$ \\
\hline ACTH (N-Terminal) & 11594 & 1084 \\
ACTH (C-Terminal) & 6028 & 591 \\
$\beta-M S H$ & 3000 & 250 \\
\hline
\end{tabular}

Note: All samples at $09.00 \mathrm{~h}$.

\section{TABLE IV}

Plasma 11-OHCS $(\mu \mathrm{g} / 100 \mathrm{ml})$ in 2 boys $\mathrm{A}$ and $\mathrm{B}$ : effects of spontaneous hypoglycaemia, time of day, and adrenocortical stimulation with tetracosactrin $(0 \cdot 25 \mathrm{mg}$ intramuscularly)

\begin{tabular}{|c|c|c|c|c|c|c|}
\hline \multirow{3}{*}{ Boy } & \multirow{3}{*}{$\begin{array}{l}\text { Hypo- } \\
\text { glycaemia }\end{array}$} & \multirow{2}{*}{\multicolumn{2}{|c|}{ Time of day }} & \multicolumn{3}{|c|}{ Tetracosactrin } \\
\hline & & & & \multicolumn{3}{|c|}{$\begin{array}{l}\text { Min after intramuscular } \\
\text { injection }\end{array}$} \\
\hline & & $09.00 \mathrm{~h}$ & $23.00 \mathrm{~h}$ & 0 & 30 & 90 \\
\hline $\begin{array}{l}\boldsymbol{A} \\
\boldsymbol{B}\end{array}$ & $\begin{array}{l}10(30) \\
22 \cdot 9(25)\end{array}$ & $\begin{array}{r}7 \cdot 2 \\
20 \cdot 7\end{array}$ & $\begin{array}{l}4 \cdot 8 \\
3 \cdot 1\end{array}$ & $\begin{array}{r}13 \cdot 9 \\
7 \cdot 4\end{array}$ & $\begin{array}{l}15 \cdot 6 \\
18 \cdot 4\end{array}$ & $\begin{array}{r}13 \cdot 9 \\
9 \cdot 1\end{array}$ \\
\hline
\end{tabular}

Note: Values in parentheses are plasma glucose in the sample in $\mathrm{mg} / 100 \mathrm{ml}$

\section{TABLE V}

Plasma concentrations of corticosteroids in 2 boys A and $\mathrm{B}$

\begin{tabular}{|c|c|c|c|c|}
\hline \multirow{3}{*}{ Compound } & \multicolumn{4}{|c|}{ Plasma (ng/100 ml) } \\
\hline & \multirow{2}{*}{$A$} & \multirow{2}{*}{$B$} & \multicolumn{2}{|r|}{ Normal } \\
\hline & & & Mean & Range \\
\hline $\begin{array}{l}\text { DOC } \\
\text { Corticosterone } \\
18-O H-D O C \\
\text { Aldosterone } \\
11-D e 0 x y \text { cortisol } \\
\text { Cortisol }\end{array}$ & $\begin{array}{l}91 \cdot 7 \\
376 \\
45 \cdot 8 \\
10 \cdot 8 \\
44 \cdot 7 \\
4800\end{array}$ & $\begin{array}{l}208 \cdot 3 \\
267 \\
27 \cdot 0 \\
5 \cdot 9 \\
67 \cdot 1 \\
5900\end{array}$ & $\begin{array}{r}10 \\
250 \\
46 \cdot 4 \\
6 \cdot 2 \\
59 \cdot 3 \\
5600\end{array}$ & $\begin{array}{r}2 \cdot 8-16(18) \\
80-800(16) \\
20-160(18) \\
4-18 \text { (20) } \\
4-400(12) \\
2500-10000(14)\end{array}$ \\
\hline
\end{tabular}

Note: Numbers of normal people studied are shown in parentheses.

reduce interference in the method used for the estimation of 11-OHCS. Plasma aldosterone was normal in both boys after maintaining a recumbent position for 15 hours overnight. Deoxycortisol was at the lower end of the normal range in $A$; similarly, 18-OH-DOC was low but normal in $B$ (Table $V$ ). The response of $A$ to a low sodium diet was tested over 5 days. This regimen 
was well tolerated both biochemically and clinically, sodium excretion falling from a normal value of 138 to 2 mmol/24 h on a diet containing less than $10 \mathrm{mmol}$ sodium/d. Daily serum electrolytes remained normal. Therefore the response of the mineralocorticoids to this situation was normal.

The parents showed a normal increase in steroid output in response to ACTH. The glucosuria noted in both parents is not normally found (Table VI); any effect the glucose may have on the 17-OHCS method was avoided by adding more sodium metaperiodate.

\section{TABLE VI}

Urinary steroid response of parents of 2 boys $\mathrm{A}$ and $\mathrm{B}$ to corticotrophin gel ( $2 \mathrm{mg} / \mathrm{kg}$ per $24 \mathrm{~h}$ for $48 \mathrm{~h}$ )

\begin{tabular}{l|c|c}
\hline & Day & $17-$ OHCS $(\mathrm{mg} / 24 \mathrm{~h})$ \\
\cline { 2 - 3 } & Father & Mother \\
\hline Basal 1 & $15 \cdot 7$ & $8 \cdot 6$ \\
Basal 2 & $10 \cdot 0$ & $7 \cdot 4$ \\
ACTH 1 & $47 \cdot 5$ & $28 \cdot 2^{\star}$ \\
ACTH 2 & $29 \cdot 5^{\star}$ & $27 \cdot 0^{\star}$ \\
\hline
\end{tabular}

^Indicates glucosuria.

Diagnosis. The pattern of clinical features suggested the diagnosis. The features were recurrent hypoglycaemia, with no evidence of electrolyte imbalance, precipitated by the stress of infection. This process started after one year of age in 2 pigmented and tall brothers. The diagnosis was made from the failure of urinary steroid response to ACTH. The very high levels of ACTH in plasma and a normal response to sodium restriction provided confirmation.

\section{Discussion}

The clinical features shown in familial glucocorticoid deficiency can suggest the diagnosis because these features provide a clear illustration of the physiological actions of cortisol, and it is interesting to note that hypoglycaemia was generally precipitated by the stress of infection in the 2 boys studied. However, not all features are invariably present.

Both brothers in the present study were tall. Heights are available for 17 of 22 recorded cases. 8 of these children were above the 97th centile for their population. Only 4, 3 from one family, were below the mean height for their ages. 2 children were at the mean height for their age. Some of the previously reported cases have shown more advanced bone maturation than their chronological age as in Case $A$. However, in the 2 brothers described in this study bone development was consistent with their height age.

The hypoglycaemia was almost certainly due to lack of cortisol-stimulated gluconeogenesis (Sayers and Travis, 1970). The anabolic effects of growth hormone and other compounds would thus be unopposed. The plasma concentrations of growth hormone in our 2 boys were normal. Therefore, peripheral imbalance appears to be the mechanism for the excessive height in familial glucocorticoid deficiency; this is consistent with other evidence (Soyka and Crawford, 1965; Root, Bongiovanni, and Eberlein, 1969; Vazquez, Schutt-Aine, and Kenny, 1972). The levels of pituitary hormones other than ACTH and $\beta-M S H$ in plasma were also unremarkable. Plasma TSH and FSH were normal, only LH may have been marginally raised. Urine concentrations of FSH and $\mathrm{LH}$ were normal. There was thus no definite evidence of marked overproduction of anterior pituitary hormones other than ACTH and $\beta$-MSH. The ACTH concentrations found in the present studies are high relative to the raised levels usually encountered in primary adrenocortical deficiency in adults as determined both by bioassay, 200-4500 pg/ml (Liddle, Island, Meador, 1962), and by radioimmunoassay, 320-1200 pg/ml (Berson and Yalow, 1968; Besser et al., 1971a). The levels of $\beta-\mathrm{MSH}$ are also high (Table IIIB), which is consistent with the chronic rise in ACTH levels (Donald and Toth, 1973).

The mechanism largely responsible for the hyperpigmentation is probably the rise in the $\beta$-MSH levels (Howe, 1973). Pigmentation was marked in 20 of 22 recorded cases, generally starting about 6-18 months of age and mainly involving the areas exposed to daylight. There is later a diffuse spread to the trunk and in boys to the genitalia. However, some children, including the second child in the present study, have become pigmented towards the end of the neonatal period.

The occurrence of the disease in the present two brothers is consistent with the suggested sex-linked recessive mode of inheritance (Migeon et al., 1968). The autosomal recessive mode is less likely (Franks and Nance, 1970).

The maintenance of normal electrolyte balance in this condition is striking. The older brother responded normally to a low sodium diet over 5 days and neither brother showed abnormalities in their serum electrolytes during their hypoglycaemic episodes. In addition the eldest boy, $A$, showed a finding previously recorded in familial glucocorticoid deficiency, namely mild swelling of the face and hands when hypoglycaemic. This might be due to the relatively high levels of the mineralocorticoid DOC in plasma and some evidence for a slight adrenocortical response to exogenous ACTH in this 
boy, hypoglycaemia producing some further rise in the DOC level which could then cause oedema, though increased DOC does not normally produce oedema. It should be noted that the urine concentrating power was within normal limits, unlike the limited ability in adults with adrenocortical insufficiency.

Some of the clinical and biochemical features outlined above could have been produced by recognized defects in the steroid hydroxylations involved in hormone biosynthesis, specifically hydroxylations at $\mathrm{C}-17$, or $\mathrm{C}-21$, or $\mathrm{C}-11$ of the steroid skeleton. The most common defect of 21-hydroxylation can be eliminated by the normal or low urinary excretion of $5 \beta$-pregnane- $3 \alpha, 17 \alpha, 21 \alpha$-triol, 17-OHCS (Table I), and 17-oxosteriods (Table II). Similarly, a defect of $11 \beta$-hydroxylation is excluded by normal plasma levels of 11-deoxycortisol, or compound $S$ (Table V) as well as normal or low urinary steroid excretion. A defect of 17-hydroxylation is exluded by normal urinary excretion and normal plasma concentrations of steroids which were, or had been, hydroxylated at C-17 (Tables I and V). In addition, both boys showed normal male development and no signs of electrolyte imbalance. Though the response to ACTH (Tables I and II) and the plasma concentrations of steroids involved in aldosterone biosynthesis shown in Table $\mathrm{V}$ reveal abnormal patterns, these are not the large alterations found in 'classical' defects of the steroid hydroxylations involved in biosynthesis.

The primary defect in familial glucocorticoid deficiency is localized in the adrenal cortex. The commonest anatomical finding has been marked hypoplasia of the zona fasciculata and zona reticullaris with a normal zona glomerulosa (Migeon et al., 1968; Kelch et al., 1972). Such findings are consistent with our results. The failure of these two ACTH-dependent zones of the adrenal cortex appears to occur at a specific stage in development, generally between one and two years of age. A deterioration in glucocorticoid production was found in the older boy, though pigmentation was noted in the younger boy as early as the end of the newborn period, suggesting that the failure can start early in life. A similar progressive failure of response to ACTH with early pigmentation was found by Moshang et al. (1973) in 2 of 5 children from one family.

A variety of evidence appears to justify the suggestion that familial glucocorticoid deficiency is due to a failure of the fetal adrenal cortex to differentiate into an adult type of ACTH responsive zona fasciculata and zona reticularis. Migeon et al., (1968) reached a similar conclusion from their in vivo and in vitro studies. The high levels of DOC in plasma appear to be important; those in the present study are similar to the results of Kelch et al. (1972) and are consistent with the high levels of ACTH because ACTH is known to stimulate DOC secretion (Brown and Strott, 1971; Schambelan and Biglieri, 1972). It also seems relevant that compared with adults there are high levels of DOC, and to a lesser extent corticosterone, in plasma from normal newborn infants (Klein, Baden, and Giroud, 1973). The high levels of DOC in the newborn may be explained by the existence of a 'fetal' 21-hydroxylation system with a preference for the 17-desoxysteroid pregnenolone, in addition to a system acting on 17 $\alpha$-hydroxyprogesterone as in the adult biosynthetic sequence (Gustafsson, Gustafsson, and Olin, 1972).

Since cortisol and other $17 \alpha$-hydroxylated steroids are produced in familial glucocorticoid deficiency, $17 \alpha$-hydroxylation systems must be present. $17 \alpha$-hydroxylation cannot be performed in the zona glomerulosa, therefore the zona glomerulosa cannot be producing all the corticosteroids found in these 2 boys. However, the relatively high levels of the 17-desoxycorticosteroid, DOC, suggest some relative deficiency of $17 \alpha$-hydroxylation. This relative deficiency is consistent with the preferential 21-hydroxylation of a 17-desoxysteroid by a 'fetal' system, which would be present in a fetal zone of the adrenal cortex. The relative deficiency of $17 \alpha-$ hydroxylation may also indicate a control point in this type of steroid biosynthesis. Such a control point may be ACTH dependent since $17 \alpha$-hydroxylation can be increased by ACTH in the rabbit (Fevold and Drummond, 1973). It may also be relevant that the stimulated activity in the rabbit has a preference for pregnenolone rather than progesterone as a substrate.

Although this is highly speculative, much of the work on the mechanism of ACTH action (Gill, 1972) does not help explain the findings in hereditary adrenocortical unresponsiveness or familial glucocorticoid deficiency, especially the anomalous falls in steroid output on ACTH stimulation in the present studies. From all the above evidence it seems probable that in glucocorticoid deficiency ACTH does slow down the atrophy of the fetal adrenal cortex which normally disappears at about 1-6 months of age (Shackleton, Mitchell, and Farquhar, 1972).

We wish to thank Dr. J. W. Farquhar for allowing us to study his patients.

\section{REFBRENCES}

Bangham, D. R., Mussett, M. V., and Stack-Dunne, M. P. (1962). The third internationational standard for corticotrophin. Bulletin of the World Health Organisation, 27, 395. 
Berson, S. A., and Yalow, R. S. (1968). Radioimmunoassay of ACTH in plasma. fournal of Clinical Investigation, 47, 2725.

Besser, G. M., Cullen, D. R., Irvine, W. J., Ratcliffe, J. G., and Landon, J. (1971a). Immunoreactive corticotrophin levels in adrenocortical insufficiency. British Medical fournal, 1, 374.

Besser, G. M., Orth, D. N., Nicholson, W. E., Byyny, R. L., Abe, K., and Woodham, J. P. (1971b). Dissociation of the disappearance of bioactive and radioimmunoreactive ACTH from plasma in man. Fournal of Clinical Endocrinology and Metabolism, 32, 595.

Brown, R. D., and Strott, C. A. (1971). Plasma deoxycorticosterone in man. fournal of Clinical Endocrinology and Metabolism, 32, 744.

Clayton, B. E., Edwards, R. W. H., and Renwick, A. G. C. (1963) Adrenal function in children. Archives of Disease in Childhood, 38, 49.

Darling, J. A. B., and Harkness, R. A. (1973). A method for the group analysis of steroids in milk. Acta Endocrinologica, 72, 391.

Darling, J. A. B., Kelly, R. W., Laing, A. H., and Harkness, R. A. (1972). The isolation and identification of progesterone obtained from cows' milk during pregnancy. fournal of Endocrinology, 54, 347.

Donald, R. A., and Toth, A. (1973). A comparison of the $\beta$ melanocyte-stimulating hormone and corticotropin response to hypoglycemia. fournal of Clinical Endocrinology and Metabolism, 36, 925.

Exley, D., and Chamberlain, J. (1967). Properties of steroidal-3enol heptafluorobutyrates. Steroids, 10, 509.

Fevold, H. R., and Drummond, H. B. (1973). Factors affecting the adrenocorticotrophic hormone stimulation of rabbit adrenal $17 \alpha$-hydroxylase activity. Biochimica et Biophysica Acta, 313, 211.

Few, J. D. (1960). A method for the analysis of urinary 17hydroxycorticosteroids. Fournal of Endocrinology, 22, 31.

Franks, R. C., and Nance, W. E. (1970). Hereditary adrenocortical unresponsiveness to ACTH. Pediatrics, 45, 43,

Fraser, I. S., Baird, D. T., Hobson, B. M., Michie, E. A., and Hunter, W. (1973). Cyclical ovarian function in women with congenital absence of the uterus and vagina. Fournal of Clinical Endocrinology and Metabolism, 36, 634.

Gill, G. N. (1972). Mechanism of ACTH action. Metabolism, 21, 571.

Gustafsson, J., Gustafsson, S., and Olin, P. (1972). Steroid excretion patterns in urine from two boys in the neonatal period with congenital adrenal hyperplasia due to 21-hydroxylase deficiency. Acta Endocrinologica, 71, 353.

Harkness, R. A., and Love, D. N. (1966). Studies on the estimation of urinary pregnanetriol during pregnancy and childhood. Acta Endocrinologica, 51, 526.

Howe, A. (1973). Mammalian pars intermedia: a review of its structure and function. Fournal of Endocrinology, 59, 385.

Hunter, W. M., and Greenwood, F. C. (1964). A radio-immunoelectrophoretic assay for human growth hormone. Biochemical fournal, 91, 43.

Irvine, W. J., Toft, A. D., Hunter, W. M., and Kirkham, K. E. (1973). An assessment of plasma TSH radioimmunoassay and of the TSH stimulation test in the diagnosis of 100 consecutive patients with suspected hypothyroidism. Clinical Endocrinology, 2, 135.

Kelch, R. P., Kaplan, S. L., Biglieri, E. G., Daniels, G. H., Epstein, C. J., and Grumbach, M. M. (1972). Hereditary adrenocortical unresponsiveness to adrenocorticotropic hormone. fournal of Pediatrics, 81, 726.

Kershnar, A. K., Roe, T. F., and Kogut, M. D. (1972). Adrenocorticotropic hormone unresponsiveness: report of a girl with excessive growth and review of 16 reported cases. Fournal of Pediatrics, 80, 610.

Klein, G. P., Baden, M., and Giroud, C. J. P. (1973). Quantitative measurement and significance of five plasma corticosteroids during the perinatal period. fournal of Clinical Endocrinology and Metabolism, 36, 944.

Liddle, G. W., Island, D., and Meador, C. K. (1962). Normal and abnormal regulation of corticotrophin secretion in man. Recent Progress in Hormone Research, Vol. 18, p. 125. Ed. by G. Pincus. Academic Press, New York and London.

Lipscomb, H. S., and Nelson, D. H. (1962). A sensitive biologic assay for ACTH. Endocrinology, 71, 13.
Mason, P. A., and Fraser, R. (1975). Estimation of aldosterone, 11-deoxycorticosterone, 18 -hydroxy -11-deoxycorticosterone, corticosterone, cortisol and 11-deoxycortisol in human plasma by gas-liquid chromatography with electron capture detection. fournal of Endocrinology, 64, 277.

Mattingly, D. (1962). A simple fluorimetric method for the estimation of free 11-hydroxycorticosteroids in human plasma. fournal of Clinical Pathology, 15, 374.

Migeon, C. J., Kenny, F. M., Kowarski, A., Snipes, C. A., Spaulding, J. S., Finkelstein, J. W., and Blizzard, R. M. (1968). The syndrome of congenital adrenocortical unresponsiveness to ACTH. Report of six cases. Pediatric Research, 2, 501.

Moshang, T., Rosenfield, R. L., Bongiovanni, A. M., Parks, J. S., and Amrhein, J. A. (1973). Familial glucocorticoid insufficiency. Fournal of Pediatrics, 82, 821.

Ney, R. L., Shimizu, N., Nicholson, W. E., Island, D. P., and Liddle, G. W. (1963). Correlation of plasma ACTH concentration with adrenocortical response in normal human subjects, surgical patients, and patients with Cushing's disease. fournal of Clinical Investigation, 42, 1669.

Ratcliffe, J. G., and Edwards, C. R. W. (1971). The extraction of adrenocorticotrophin and arginine-vasopressin from human plasma by porous glass. Radioimmunoassay Methods, p. 502 . Ed. by $K$. E. Kirkham and W. M. Hunter. Churchill Livingstone, Edinburgh.

Rees, L. H., Cook, D. M., Kendall, J. W., Allen, C. F., Kramer, R. M., Ratcliffe, J. G., and Knight, R. A. (1971). A radioimmunoassay for rat plasma ACTH. Endocinology, 89, 254.

Root, A. W., Bongiovanni, A. M., and Eberlein, W. R. (1969). Studies of the secretion and metabolic effects of human growth hormone in children with glucocorticoid-induced growth retardation. Fournal of Pediatrics, 75, 826.

Sayers, G., and Travis, R. H. (1970). Adrenocorticotrophic hormone; adrenocortical steroids and their synthetic analogs. The Pharmacological Basis of Therapeutics, 4th ed., p. 1616. Ed. by L. S. Goodman and A. Gilman. Macmillan, New York, London, and Toronto.

Schambelan, M., and Biglieri, E. G. (1972). Deoxycorticosterone production and regulation in man. Fournal of Clinical Endocrinology and Metabolism, 34, 695.

Shackleton, C. H., Mitchell, F. L., and Farquhar, J. W. (1972), Difficulties in the diagnosis of the adrenogenital syndrome in infancy. Pediatrics, 49, 198

Shepard, T. H., Landing, B. H., and Mason, D. G. (1959). Familial Addison's disease. American fournal of Diseases of Children, 97, 154.

Soyka, L. F., and Crawford, J. D. (1965). Antagonism by cortisone of the linear growth induced in hypopituitary patients and hypophysectomized rats by human growth hormone. fournal of Clinical Endocrinology and Metabolism, 25, 469.

Stempfel, R. S., and Engel, F. L. (1960). A congenital, familial sydrome of adrenocortical insufficiency without hypoaldosteronism. Fournal of Pediatrics, 57, 443.

Tanaka, K., Budd, M. A., Efron, M. L., and Isselbacher, K. J. (1966). Isovaleric acidemia: a new genetic defect of leucine metabolism. Proceedings of the National Academy of Sciences, 56, 236.

Tanner, J. M., Whitehouse, R. H., and Healy, M. J. R. (1962). $A$ New System for Estimating Skeletal Maturity from the Hand and Wrist, with Standards Derived from a Study of 2600 Healthy British Children, parts I and II. Centre International de l'Enfance, Paris.

Vazquez, A. M., Schutt-Aine, J. C., and Kenny, F. M. (1972). Effect of cortisone therapy on the diurnal pattern of growth hormone secretion in congenital adrenal hyperplasia. fournal of Pediatrics, 80, 433.

Williams, H. E., and Freeman, M. (1965). Primary familial Addison's disease. Australian Paediatric fournal, 1, 93.

Wilson, A. (1973). Measurement and mechanism of steroid hormones. Ph.D. Thesis. University of Glasgow.

Wilson, A., and Fraser, R. (1971). The estimation of plasma 11deoxycorticosterone in man using gas-liquid chromatography with electron capture detection. Fournal of Endocrinology, $51,557$.

Correspondence to Dr. R. A. Harkness, Department of Paediatric Biochemistry, Royal Hospital for Sick Children, 1 Rillbank Crescent, Edinburgh EH9 1LJ. 